\title{
Effects of Hormone Replacement Therapy (HRT) on the body weight, blood pressure and vaginal bleeding in menopausal women
}

\author{
A. Baziad
}

\begin{abstract}
Abstrak
Penelitian ini merupakan penelitian retrospektif deskriftif yang dilakukan pada 29 pasien menopause. Setiap pasien mendapatkan pengobatan dengan estrogen equin konjugasi (EEK) $0,625 \mathrm{mg} / \mathrm{hari}+$ medroxyprogesterone acetate (MPA) $5 \mathrm{mg} / \mathrm{hari}$ kontinus selama 6 bulan. Usia rata-rata menopause adalah 53, 7 tahun dengan lama menopause 5,5 tahun. Tingkat pendidikan pasien adalah SMA keatas. Selama 6 bulan continuous combined HRT dijumpai peningkatan berat badan dan tekanan darah sistolik yang bermakna, sedangkan tekanan darah diastolik tidak mengalami perubahan yang berarti. Perdarahan vaginal berupa spotting terjadi pada $69 \%$ selama pasien menggunakan continuous combined HRT. (Med J Indones 2002; 11:11-4)
\end{abstract}

\begin{abstract}
This study was a descriptive, retrospective trial conducted in 29 menopausal women. Each patient received treatment with conjugated equine estrogen(CEE) $0.625 \mathrm{mg} / \mathrm{day}+$ medroxyprogesterone acetate (MPA) $5 \mathrm{mg} / \mathrm{hari}$ continuously for the period of 6 months. The average age of menopause was 53.7 years with duration of menopause of 5.5 years. The education level of patients was Senior High School and higher. During the period of 6 months of continuous combined HRT, a significant increase of body weight and systolic blood pressure was found, while diastolic blood pressure did not have any significant change. Vaginal bleeding in the form of spotting occurred in $69 \%$ of the patients during the use of continuous combined HRT. (Med J Indones 2002;11:11-4)
\end{abstract}

Keywords: continuous HRT, menopause, body weight, blood pressure, bleeding

Menopause occurring as a result of estrogen deficiency creates short-term and long-term health problems. Short-term complaints frequently assume the form of hot flushes, psychological symptoms such as fear, tension, depression, melancholy mood, fatigue, urogenital condition of atrophy, insomnia, headache, myalgia, libido disorder, and palpitating heart. Longterm complaints include the increased incidence of bone fractures due to osteoporosis, coronary heart disease, disorder of lipid metabolism, dementia, stroke, and the increased incidence of colorectal cancer.

These complaints occur as a result of deficiency in estrogen hormone, and their management is carried out by the administration of estrogen hormone, with or without combination with progesterone, which is known as hormone replacement therapy (HRT). It has

Departement of Obstetrics and Gynecology, Faculty of Medicine University of Indonesial Dr Cipto Mangunkusumo General Hospital, Jakarta, Indonesia been proved that HRT may eliminate short-term complaints, and may prevent menopausal women from bone fractures, coronary heart disease, stroke, dementia, and colorectal cancer. However, the use of HRT in both developed and developing countries is still low. Patient's compliance in using HRT is still low. Several factors accounting for the low use of HRT include vaginal bleeding, increased body weight, and fear on breast cancer. Vaginal bleeding and increasing body weight are common causes of concern and inconvenience to HRT users; it has a major impact on compliance. In the countries in which the majority of population is Moslem, vaginal bleeding creates an extremely important problem as it is considered to interfere with religious practices.

Vaginal bleeding occurring is closely associated with the method of HRT administration and the type of estrogen and progesterone used. A sequentially combined HRT regime has a scheduled episode of withdrawal bleeding at the end of the progestagen phase, and most women in Indonesia find this method unlik- 
able. In order to deal with this problem, continuously combined HRT can be administered. Continuous administration of progestogens in combination with oestrogen, or the use of other compounds e.g tibolone has been advocated to overcome the scheduled withdrawal bleeding associated with sequentially combined HRT regimen. ${ }^{1,2}$ However, the continuous administration of combined HRT still creates problems, such as spotting. A high incidence of spotting (40-50\%) has been observed in many studies of continuously HRT administration. ${ }^{1,3}$

Almost all HRT regimens can cause increasing body weight, and such increase is only temporary. Administration of progestogens in combination with oestrogen can increase blood pressure, but this increase is not pathologic.

The present study attempted to observe the effects of continuous administration of combined HRT on body weight, blood pressure, and the incidence of bleeding in menopausal women receiving HRT for a period of 6 months.

\section{METHODS}

The subjects of the study were taken from the medical records of female menopausal patients with various climacteric complaints admitted to Menopause Clinic "Menox" in Jakarta for treatment. As many as 129 patients were collected from January 2000 to June 2000 . However, those who had complete data and met the requirements to be processed were 29 patients. A data identification was done on:

1. Patient's age, last menstruation, education, and main complaints,

2. Physical examinations (body weight and blood pressure),

3. Pap's smear and breast mammography,

4. Incidence of bleeding

Each patient received the therapy with conjugated estrogen (CEE) tablet $0.625 \mathrm{mg} / \mathrm{day}+$ medroxyprogesterone acetate $5 \mathrm{mg} /$ day continuously, and took these regimens for 6 months consecutively. Menopause was established by the examination of FSH hormone. Spotting here refers to any vaginal blood loss for which no protection is used (WHO), whereas unscheduled bleeding is any unscheduled vaginal blood loss. This study was open trial retrospectivedescriptive method.

\section{RESULTS}

Table 1. Education level of patients

\begin{tabular}{lcc}
\hline & Frequency & $\%$ \\
\hline Primary School & 3 & 10.3 \\
Senior High School & 11 & 37.9 \\
University Undergraduate & 7 & 24.1 \\
University graduate & 8 & 27.6 \\
\hline Total & 29 & 100 \\
\hline
\end{tabular}

Table 2. Effect of HRT on body weight

\begin{tabular}{lcccc}
\hline Remarks & $\begin{array}{c}\text { Early } \\
\text { body weight } \\
(\mathrm{kg})\end{array}$ & $\begin{array}{c}\text { Body weight } \\
\text { after } \\
6 \text { months }\end{array}$ & t & p \\
\hline Body weight & $59.4 \pm 11.28$ & $60.9 \pm 11.17$ & -5.161 & $<0.01$ \\
\hline
\end{tabular}

Table 3. Effect of HRT on blood pressure

\begin{tabular}{lcccc}
\hline \multicolumn{1}{c}{ Remarks } & $\begin{array}{c}\text { Early } \\
\text { blood pressure } \\
(\mathrm{mmHg})\end{array}$ & $\begin{array}{c}\text { Blood pressure } \\
\text { after 6 months } \\
(\mathrm{mmHg})\end{array}$ & $\mathrm{t}$ & $\mathrm{P}$ \\
\hline $\begin{array}{l}\text { Systolic } \\
\text { blood pressure }\end{array}$ & $136.2 \pm 16.34$ & $139.0 \pm 3.03$ & -2.289 & $<0.05$ \\
$\begin{array}{l}\text { Diastolic } \\
\text { blood pressure }\end{array}$ & $87,4 \pm 7,74$ & $89,0 \pm 7,2$ & $-0,828$ & $>0,05$ \\
\hline
\end{tabular}

Table 4. Vaginal bleeding during 6-month HRT

\begin{tabular}{c|c|c|c}
\hline \multicolumn{2}{c|}{ Bleeding $(t)$} & \multicolumn{2}{c}{ Bleeding (-) } \\
\hline $\begin{array}{c}\text { Number of } \\
\text { patients }\end{array}$ & $\%$ & $\begin{array}{c}\text { Number of } \\
\text { patients }\end{array}$ & $\%$ \\
\hline 20 & 69 & 9 & 31 \\
\hline
\end{tabular}

\section{DISCUSSION}

The average age of menopause was 53.7 years or \pm 6.23 years, and duration of menopause of 5.5 years or \pm 3.90 years. In terms of menopause age, such age was not too different from that in the developed countries, i.e. between 51 and 52 years. ${ }^{4}$ This may be attributed to the fact that the level of welfare between these countries were not too different. 
In this study, the subjects have experienced menopause since 5.5 years ago with the education level of Senior High School and higher (Table 1). Thus, half of the subjects have arrived at the postmenopausal stage with a variation of climacteric complaints. The education level of patients played a crucial role in the treatment of menopause since each patient was expected to take the medications regularly and appropriately. Missing one or two tables each day would increase the incidence of bleeding.

From the statistical test undertaken it showed that there was a significant increase of body weight $(p<0.01)$. In fact, estrogen will not, or if any, only very slightly cause body weight gain. Although highdose estrogen such as $8 \mathrm{mg}$ estriol or $4 \mathrm{mg}$ estradiol valerat, or $5 \mathrm{mg}$ conjugated equine estrogens is administered, body weight gain is rarely encountered. ${ }^{5,6} \mathrm{Un}$ fortunately, most patients kept blaming HRT. By contrast, women with estrogen deficiency will tend to gain more body weight as a result of fat accumulation in the body. The administration of $\mathrm{Gn}-\mathrm{RH}$ analog for 6 months resulted in the estrogen synthesis in the ovaries, and consequently body weight gain of $0.8 \mathrm{~kg}$ and accumulation of fat mass of $2 \mathrm{~kg}$ will occur. ${ }^{7}$ This may explain the fact that HRT does not cause increasing body weight. HRT may stimulate appetite at hypothalamus such that the patient will always want to eat, and thereby the frequency of food intake will increase. This is the reason why an increasing body weight occurs. In the present study, it is evident that there was a significant increase of body weight. From the history taking, it shows that patients frequently ate between meals in a large quantity.

Generally, in the beginning of HRT administration a body weight gain of $1-2 \mathrm{~kg}$ will occur, and this increase will be temporary. As a result of estrogen deficiency, body tissues are deficient of fluid, and with estrogen administration rehydration will occur which is a physiological process. Body tissues such as skin contain mucopolysaccaride (hyaluronate acid) and protein which can keep water. Hyaluronate acid is a polymer from $\mathrm{N}$-Acetylglucosamine and glucuronate acid which can bind $25 \%$ of the water present in the tissues.

After menopause a sclerotic change will occur in the blood vessels which may lead to the increase of blood pressure, particularly systolic blood pressure, while diastolic blood pressure does not change. In $1-2 \%$ of menopausal women, HRT administration may increase blood pressure, particularly systolic blood pres- sure, and this increase does not reach any hazardous value. 'Several other studies, however, did not find any increase of either systolic or diastolic blood pressure, ${ }^{8,9}$ since estrogen triggers the production of prostacyclines in the endothelial cells of blood vessels, and reduces the production of Endothelin 1. Prostacycline has vasodilatory effects, while Endothelin 1 has vasoconstrictive effects. In addition, estrogen has direct effects on the cells of smooth muscles through the inhibition of calcium entry into the cells. Even the administration of estronsulfate 0.625 $\mathrm{mg}$ and $2.5 \mathrm{mg} /$ day resulted in the significant decrease of systolic and diastolic blood pressures. ${ }^{10}$ However, there is a slight increase of blood pressure after the administration of equine estrogen $0.3 \mathrm{mg}$ up to $5 \mathrm{mg}$ with or without progesterone. ${ }^{11}$

In this study, after HRT administration with conjugated equine estrogen(CEE) $0.625 \mathrm{mg} /$ day combined with medroxyprogesterone acetate (MPA) $5 \mathrm{mg} /$ day for 6 months, a significant increase of systolic blood pressure was observed ( $p>0.05$ ), while diastolic blood pressure remained within normal limits.

Vaginal bleeding constituted the main reason for most women to terminate the use of HRT. Vaginal bleeding such as spotting was frequently encountered in continuous combined HRT rather than sequential combined HRT. In almost $40-50 \%$ of patients, spotting occurred in the first 6 months of continuous combined HRT. ${ }^{1,2,3}$ It is worth noting that the spotting occurring is not associated with menstruation but with bleeding due to medications, such that it did not annul the religious practices by Moslems. Bleeding such as spotting does not require special management; however, if it does not stop after a certain period of time it is necessary to identify the causal factor of such spotting. ${ }^{12,13}$ In this study, during the use of continuous combined HRT for 6 months it was found that $69 \%$ of bleeding occurring was spotting. Generally, patients could accept such bleeding and no one discontinue using HRT.

\section{CONCLUSIONS}

The average age of menopause was 53.7 years and duration of menopause was 5.5 years. The education level of patients was Senior High School and higher. During the continuously combined HRT, a significant increase of body weight occurred. In addition, a significant increase of systolic blood pressure was observed; however, the diastolic blood pressure did not 
undergo significant change. Vaginal bleeding in the form of spotting as much as $69 \%$ occurred during the continuously combined HRT.

\section{REFERENCES}

1. Staland B. Continuous treatment with natural oestrogens and progestogens. A method to avoid endometrial stimulation. Maturitas 1981; 3:145-56

2. Kuhl H. Klimakterium, Postmenopause und Hormonsubstitution, Uni-Med, Uni-med Verlag, Bremen, 1999: 137 138

3. Mattsson LA, Cullberg G, Samsioe G. Evaluation of continuous oestrogen-progestagen regimen for climacteric complaints . Maturitas 1982; 4 : 95-102

4. Birkhauser M, Braendle W, Breckwoldt M, Keller PJ, Kuhl H, Runnenbaum B. Empfelungen des 'Zurcher Gesprachskreises ' zur Substitution mit Estrogenen und Gestagenen im Klimakterium und in der Postmenopause. Frauenarzt 1999; 40:153-55

5. Tzingounis VA, Aksu MF, Greenblatt. The significance of oestriol in the management of the post-menopause. Acta endocr $1980 ; 233: 45-5$

6. Utian WH. Effect of postmenopausal estrogen therapy on diastolic blood pressure and body weight. Maturitas 1978; $1: 3-8$
7. Revilla R, Revilla M, Villa LF, Cortes J, Arribas I, Rico H. Changes in body composition in women treated with gonadotropin-releasing hormone agonist. Maturitas 1998; 31:822-24

8. Hassager C, Riis BJ, Strom V, Guyene TT, Christiansen C. The long-term effect of oral and percutaneous estradiol on plasma renin substrate and blood pressure. Circulation $1987 ; 76: 753-8$

9. The Writing Group for the PEPI Trial. Effect of estrogen or estrogen/progestin regimens on heart disease risk factors in postmenopausal women. The Postmenopausal Estrogen/Progestin Interventions (PEPI) Trial. J Am Med Assoc 1995; 8:199-208

10. Wren BG, Routledge DA. Blood pressure changes: oestrogens in climacteric women. Med J Aust 1981; 2:52831

11. Lind T, Cameron EC, Hunter WM, Leon C, Moran PF, Oxley A, Gerrard J. A prospec tive, controlled trial of six forms of hormone replacement therapy given to postmenopausal receiving lower doses of natural estrogen replacement. Obstet Gynec 1983; 62:94- 8

12. Spencer CP, Cooper AJ, Whitehead MI : Management of abnormal bleeding in women receiving hormone replacement therapy. Br Med J 1997; 315:37-42

13. Gerber B, Krause A, Quasmeh A, Rohde E, Reimer T, Friese K. Stellenwert der Hysteroskopie und fraktionierten Abrasio in der Abklarung von Postmenopause-blutungen. Geburth Frauenheilk 1998; 58:440- 45 